\title{
Osebna asistenca in uporabniška izkušnja
}

\author{
Vključenost in ovrednotenje uporabniške izkušnje v \\ strokovnih komisijah
}

\begin{abstract}
Leta 2019 je z določenimispremembami in popravki Zakona o spremembah in dopolnitvah Zakona o osebni asistenci začel veljati nov Zakon o osebni asistenci. Po njem posameznikovo potrebo po osebni asistenci ocenjuje strokovna komisija. Napiše usklajeno strokovno mnenje, na podlagi tega pa lokalni centri za socialno delo izdajo odločbo, v kateri je določena vsebina osebne asistence in število ur, ki posamezniku glede na njegove potrebe pripadajo. Prispevek se ukvarja z vprašanjem vključenosti in ovrednotenjem uporabniške izkušnje v strokovnih komisijah. Po zakonu in trenutni praksiosebez izkušnjo oviranostivstrokovnih komisijah sodelujejo kot izvedencisocialnega varstva alikot predstavniki uporabnikov, čese vlagateljodloči, dasivsvoji komisijipredstavnika uporabnikov želi. Raziskava, izvedena leta 2019, dokazuje, da je vključenost oseb z izkušnjo oviranosti v strokovne komisije ključna za uspešnost ocene, saj zmanjšuje možnost pristranskega ocenjevanja zaradi predsodkov do oseb z različnimi oviranostmi in nerazumevanja njihovih realnih sposobnosti. Zaradi podobne življenjske izkušnje in poznavanja področja se hitreje vzpostavi zaupen odnos, ki omogoča dovolj natančen vpogled $v$ življenje posameznika za realno oceno potreb po osebni asistenci.

Ključne besede: oviranost, neodvisno življenje, ocenjevanje, empatija, predstavniki uporabnikov, invalidi.
\end{abstract}

Mirjana Borenović je doktorska študentka teologije, ki deluje na področju socialnega varstva in človekovih pravic. V strokovnih komisijah po zakonu o osebni asistenci že od samih začetkov sodeluje kot izvedenka socialnega varstva. Kontakt: mirjana@svelipa.si.

\section{Personal assistance and user experience: inclusion and evaluation of user experience in expert commissions}

In the 2019, a new Personal Assistance Act came into force with certain amendments and corrections. According to it, the individual's need for personal assistance is evaluated by the expert commission which produces a shared opinion about the contents and extent of personal assistance. The paper deals with the issue of inclusion and evaluation of user experience in the expert commissions. According to the law and current practice, people with disabilities can participate in the expert commissions as social work experts or as user representatives, if the applicant wishes to have a representative in his/her commission. The research done in 2019 proves that the involvement of people with disabilities in the expert commissions is essential for the success of the assessment, as it reduces the possibility of biased assessment based on prejudices against people with disabilities and the lack of understanding of their real abilities. Due to a similar life experience and knowledge of the field, a trusting relationship is established more quickly, which enables a sufficiently precise insight into the life of the individual so that a realistic assessment of the individual's need for personal assistance can be made.

Key words: disability, independent living, evaluation, empathy, user representatives, disabled.

Mirjana Borenović is a doctoral student of theology and works in the fields of social work and human rights. From the very beginnings, she has been a part of expert commissions for personal assistance where she works as a social work expert. Contact: mirjana@svelipa.si.

\section{Uvod}

V zadnjih trinajstih letih so se v Sloveniji kot posledica začetka veljavnosti Konvencije o pravicah invalidov (Uršič, 2008) in torej sprejema zakonodaje, ki uresničuje usmeritve te konvencije, zgodile velike spremembe v demografiji in osebnih pričakovanjih oseb z oviranostmi. Dvignili sta se izobrazbena raven in stopnja zaposlenosti oseb z oviranostmi, ozaveščanje javnosti in aktivizem sta 
pospešila inkluzijo, napredek $\mathrm{v}$ medicini pa je marsikateri osebi $\mathrm{z}$ oviranostjo izboljšal kakovost življenja. Z mednarodnim gibanjem za pravice invalidov, ki je zahtevalo nove in ustvarjalne pristope pri uveljavljanju njihovih pravic in osebnih izbir (Roulstone in Hwang, 2015), se je pojavila tudi zahteva po državno financirani osebni asistenci. Za osebe z različnimi oviranostmi, ki v svojem vsakdanjem življenju potrebujejo pomoč druge osebe, je pravica do osebne asistence ključni prvi pogoj za doseganje samostojnosti in življenja v skupnosti (Doty, Kasper in Litvak, 1996). Dostop do storitev osebne asistence pozitivno vpliva na samoodločanje in kakovost življenja oseb z različnimi oviranostmi (Saxton, 2002).

V članku se bom ukvarjala z vprašanjem vključenosti in ovrednotenjem uporabniške izkušnje v strokovnih komisijah. Po Zakonu o osebni asistenci (2017) in trenutni praksi osebe z izkušnjo oviranosti v strokovnih komisijah sodelujejo kot izvedenci socialnega varstva ali kot predstavniki uporabnikov, če se vlagatelj odloči, da si v svoji komisiji predstavnika uporabnikov želi. V članku bom predstavila raziskavo, izvedeno leta 2019, ki dokazuje, da je vključenost oseb z izkušnjo oviranosti v strokovne komisije ključna za uspešnost ocene, saj zmanjšuje možnost pristranskega ocenjevanja zaradi predsodkov do oseb z različnimi oviranostmi in nerazumevanja njihovih realnih sposobnosti. Zaradi podobne življenjske izkušnje in poznavanja področja se hitreje vzpostavi zaupen odnos, ki omogoča dovolj natančen vpogled v življenje posameznika za realno ocenitev potreb po osebni asistenci.

$\mathrm{V}$ članku prepoznavam različnost ovir in osebnih okoliščin, vendar se za namen članka omejujem predvsem na gibalno ovirane osebe, ki zaradi svoje oviranosti potrebujejo pomoč druge osebe in so po Zakonu o osebni asistenci upravičenke in uporabnice osebne asistence. Ko v nadaljevanju članka pišem o osebah z oviranostmi, mislim predvsem na gibalno ovirane upravičence do osebne asistence.

\section{Sestava strokovne komisije in komisijsko ocenjevanje}

V skladu s Konvencijo o pravicah invalidov je bil v Sloveniji 17. 2. 2017 sprejet Zakon o osebni asistenci. Veljati je začel 1. 1. 2019. Njegov namen je omogočiti posamezniku oziroma posameznici z dolgotrajnimi telesnimi, duševnimi, intelektualnimi ali senzoričnimi okvarami, ki jo v povezavi z različnimi ovirami lahko omejujejo, da bi enako kot drugi polno in učinkovito sodelovala v družbi na vseh področjih življenja, omogočiti enake možnosti, večjo neodvisnost, aktivnost in enakopravno vključenost v družbo (1. člen Zakona o osebni asistenci). Sama definicija osebne asistence pa je v 2. členu opredeljena kot:

pomoč uporabniku pri vseh tistih opravilih in dejavnostih, ki jih uporabnik ne more izvajati sam zaradi vrste in stopnje invalidnosti, a jih vsakodnevno potrebuje doma in izven doma, da lahko živi neodvisno, aktivno in je enakopravno vključen $\mathrm{v}$ družbo.

Zakon o osebni asistenci v 20. in 21. členu določa, da oseba, ki želi pridobiti pravico do osebne asistence, na pristojnem centru za socialno delo odda vlogo 
za pridobitev pravice do osebne asistence. ${ }^{1}$ Potem jo obišče strokovna komisija ter izdela mnenje o številu ur in vsebini osebne asistence. Na podlagi tega izda odločbo o pravici do osebne asistence.

V sami vlogi za pridobitev pravice do osebne asistence se mora oseba med drugim odločiti tudi, kakšno sestavo strokovne komisije želi. ${ }^{2}$ Odloči se lahko, ali v strokovni komisiji, ki jo bo obiskala na domu in izdelala izvedensko mnenje, želi predstavnika uporabnikov po vrstah invalidnosti. Drugega člana strokovne komisije je do konca leta 2019 določala Skupnost centrov za socialno delo (z letom 2020 pa koordinator invalidskega varstva na pristojnem centru za socialno delo) in je lahko strokovnjak s področja socialnega ali zdravstvenega varstva. ${ }^{3}$ Če oseba v vlogi za pridobitev pravice do osebne asistence opredeli, da kot člana strokovne komisije ne želi predstavnika uporabnikov, strokovno komisijo sestavljata strokovnjak s področja zdravstva in strokovnjak s področja socialnega varstva (Sušec, 2018).

Komisija osebo, ki je vložila vlogo, obišče na domu in na podlagi dvodelnega strukturiranega pogovora ugotovi upravičenost do osebne asistence. Ta se izrazi v komisijskem mnenju o številu ur in vsebini osebne asistence (Zakon o spremembah in dopolnitvah Zakona o osebni asistenci, 2018). Komisijsko ocenjevanje je sestavljeno iz dveh delov. V prvem delu je treba med pogovorom $\mathrm{s}$ prihodnjim uporabnikom osebne asistence zapisati njegovo življenjsko zgodbo in njegove osebne podatke, drugi del pa je sestavljen iz strukturiranega pogovora na podlagi ocenjevalnega obrazca ZOjA. ${ }^{4}$

Življenjska zgodba ${ }^{5}$ vključuje posameznikove izjemno osebne vidike življenja, kot so vrsta oviranosti, status aktivnosti, tip gospodinjstva, katere medicinsko-tehnične pripomočke uporablja, socialno omrežje in aktivnosti zunaj doma. Vse to podrobno pojasnjuje življenjske okoliščine osebe. Poleg omenjenega se osebo prosi, naj pojasni svoj običajen potek dneva in navede

1 V primeru, da oseba ni poslovno sposobna in ima zakonitega zastopnika, vlogo koordinatorju invalidskega varstva na pristojnem centru za socialno delo odda njen zakoniti zastopnik.

2 Vsi člani strokovnih komisij, tako strokovnjaki socialnega in zdravstvenega varstva kakor predstavniki uporabnikov po vrstah invalidnosti, morajo pred začetkom izvajanja svoje aktivnosti kot člani strokovnih komisij opraviti posebno usposabljanje, ki ga organizira Skupnost centrov za socialno delo Slovenije. Ob koncu bodoči člani komisij, ki so uspešno opravili usposabljanje, pridobijo potrdilo o usposobljenosti. Poleg osnovnega usposabljanja pred začetkom aktivnega dela v strokovnih komisijah se morajo strokovni izvedenci vsako leto vsaj en delovni dan dodatno usposabljati za opravljanje del v povezavi z osebno asistenco (Zakon o spremembah in dopolnitvah Zakona o osebni asistenci, 2018).

3 Prvotno sprejet zakon je predvideval širšo sestavo strokovne komisije, ki bi bila sestavljena iz treh izvedencev: strokovnjaka s področja socialnega varstva, strokovnjaka s področja zdravstva in predstavnika uporabnikov (Zakon o osebni asistenci, 2017). Vendar Zakon o spremembah in dopolnitvah Zakona o osebni asistenci zmanjšuje število izvedencev na dva. Na željo posameznika ali njegovega zakonitega zastopnika je lahko en član komisije predstavnik uporabnikov po vrstah invalidnost, drugi pa izvedenec socialnega ali zdravstvenega varstva. Osebe z izkušnjo oviranosti so po trenutni praksi lahko v strokovno komisijo vključene kot izvedenke za vsa tri področja.

4 Ocenjevalni obrazec, s katerim se ocenjuje potrebo po osebni asistenci, je imenovan ZOjA, ker je utemeljen na Zakonu o osebni asistenci.

5 Življenjska zgodba osebe je del obrazca Mnenje o številu ur in vsebini osebne asistence. 
vso formalno in neformalno oskrbo, ki jo prejema. Komisijsko ocenjevanje poteka na domu prihodnjega uporabnika osebne asistence, to pomeni, da mora oseba privoliti v to, da oba člana komisije spusti v svoj osebni prostor. Komisija v svoje mnenje zapiše tudi stanje prilagojenosti stanovanja ali hiše, splošne bivalne razmere in okolje, kjer živi, ter prilagojenost ožjega in širšega bivalnega, delovnega in izobraževalnega okolja. Osebo se na koncu prosi tudi, da se samooceni glede svojega splošnega počutja in razpoloženja, odnosa do življenja, stopnje samostojnosti in obsega potreb po tuji pomoči.

Drugi del komisijskega obiska sestavlja strukturiran pogovor na podlagi ocenjevalnega obrazca ZOjA, ki je namenjen ugotavljanju upravičenosti do osebne asistence. Ocenjevalni obrazec vsebuje osem modulov ${ }^{6}$ oziroma področij ocenjevanja, $v$ katerih se ocenjuje posameznikova stopnja samostojnosti in torej potreba po pomoči druge osebe pri pomembnih vsakodnevnih dejavnostih.

Pogovor s prihodnjim uporabnikom osebne asistence, ki sledi strukturi življenjske zgodbe in ocenjevalnega obrazca ZOjA, od njega zahteva, da komisijskima članoma zaupa izjemno intimne podrobnosti svojega osebnega življenja. Za uspešen komisijski obisk in oceno ter realno napisano mnenje je potrebno, da se hitro in uspešno vzpostavi zaupen odnos med prihodnjim uporabnikom osebne asistence in članoma komisije, še posebej s članom komisije, ki vodi pogovor. Ključni za vzpostavitev zaupnega odnosa sta čuječnost in empatija, $\mathrm{k}$ temu pa pomembno pripomore tudi osebna izkušnja oviranosti vsaj enega člana komisije ali njegova uporabniška izkušnja. Tudi Evropska mreža za neodvisno življenje priporoča, naj bo ocenjevalni proces za ugotavljanje potreb po osebni asistenci jasen in transparenten, naj ga čim bolj usmerja prihodnji uporabnik osebne asistence s pomočjo drugih uporabnikov osebne asistence oz. druge osebe z oviranostjo, ki so za ocenjevanje posebej izšolane. Poudarek naj bo na izobraževanju in usposabljanju ocenjevalcev na področju odnosov (zaupnost, komunikacija, čustva ipd.) (Mladenov, Pokern in Bulic Cojocariu, 2019). Sovrstniška podpora se priporoča tudi v nadaljevanju, ko oseba že prejema storitve osebne asistence (Caputo Janhager, 2019).

\section{Čuječnost v strokovnih komisijah}

Izraz čuječnost ima več pomenov, ki se med seboj smiselno povezujejo. Beseda čuječen ima v vsakdanjem pogovornem jeziku sopomenke, kot so pozoren, bister, skrben, ozaveščen oz. obveščen, zavedajoč se, previden, pazljiv, preudaren

$6 \quad$ V prvem modulu se ocenjuje sposobnost za vzdrževanje, spreminjanje svojega položaja in gibanja, v drugem modulu se ocenjujejo kognitivne sposobnosti in aktivnosti (sposobnost za razumevanje, prepoznavanje, odločanje, usmerjanje) ter komunikacijske sposobnosti, v tretjem modulu se vrednotijo vedenjske in psihične težave, ki so posledica zdravstvenega stanja in je pri njihovem obvladovanju potrebna pomoč druge osebe. V četrtem modulu se ocenjuje sposobnost osebe, da skrbi zase (umivanje, oblačenje, slačenje, pitje, hranjenje ipd.), treba je tudi zapisati, ali je oseba inkontinentna in ali se hrani parenteralno ali po sondi oz. stomi. V petem modulu se vrednoti samostojnost in pogostost potrebe po pomoči druge osebe pri zdravniško predpisanih terapevtskih ukrepih. $V$ naslednjih treh modulih se ocenjuje sposobnost za samostojno izvajanje aktivnosti v vsakdanjem življenju in pri ohranjanju socialnih stikov, pri aktivnostih zunaj domačega okolja in pri gospodinjskih opravilih ter potrebo po morebitni pomoči druge osebe. (Inštitut Republike Slovenije za socialno varstvo, 2018) 
in moder. Izraz se v šolskem in drugem izobraževalnem procesu uporablja za označevanje odprtosti, svobodomiselnosti in izogibanju prehitrim sklepom. V kontemplativnem kontekstu izraz čuječnost označuje sposobnost biti navzoč v sedanjosti in brez predsodkov, brez obsojanja (Siegel, 2010). V psihoterapevtski obravnavi in v podobnih strokovnih komisijah, $\mathrm{v}$ katerih se morajo posamezniki odpreti, besedo čuječnost hkrati razumejo $v$ vseh treh pomenih.

Siegel (2010) pozorno in neobsojajočo navzočnost oz. čuječnost kot stanje zavedanja, ki nam omogoča fleksibilnost in receptivnost, označuje kot najpomembnejši element pomoči drugemu. Oseba, ki je čuječna, je zavestno navzoča ob drugi osebi, do nje, njene resničnosti in dogodkov je odprta, spoštljiva in ne obsoja. Kljub zahtevnosti vzpostavitve takšnega odnosa ${ }^{7}$ je ključno, da ga strokovni delavci ( $v$ našem primeru člana komisije) prevzamejo v celoti, če želijo vzpostaviti zaupen odnos, v katerem se prihodnji uporabnik osebne asistence počuti dovolj varnega odpreti se in ocenjevalcem zaupati svoje najintimnejše plati življenja.

Prihodnji uporabnik osebne asistence se mora med ocenjevanjem počutiti sproščenega, sprejetega, videnega in slišanega, tako na zavestni kot nezavedni ravni. Prav pri občutku sprejetosti, varnosti in sproščenosti pa ima ključno vlogo telo, ki sporoča naša občutje in sprejema občutja ter neverbalno govorico drugih. Članoma komisije njuno telo in opazovanje govorice telesa prihodnjega uporabnika osebne asistence lahko pomagajo pri ocenjevanju, saj biti navzoč pomeni tudi biti odprt za sporočila lastnega telesa v obliki intuicije, ki lahko usmerja k podrobnejšim vprašanjem in torej k resnični potrebi prihodnjega uporabnika osebne asistence. Telo namreč zmeraj govori resnico in se ne moti (Gostečnik, Cvetek, Repič Slavič in Pate, 2016), zato je smiselno zaupati njegovi modrosti.

Prav nasprotno pa lahko telo člana komisije izda njegovo morebitno nelagodje, zadrego ali strah, to pa prihodnji uporabnik osebne asistence zazna in se zato zaradi občutka nesprejetosti zapre vase in pomanjkljivo odgovarja na ocenjevalna vprašanja, to pa lahko negativno vpliva na samo oceno. Takšni situaciji se je treba med komisijskim ocenjevanjem čim bolj izogibati, zato je smiselno, da so člani komisije osebe, ki nimajo strahu pred osebami z različnimi vrstami oviranosti ali predsodkov do drugačnosti. Kot koristno se kaže tudi, da imajo neposredno ali posredno izkušnjo drugačnosti.

\section{Empatija vstrokovnih komisijah}

Hribar Sorčan (2008) empatijo opredeli kot sposobnost posameznika, da se postavi na mesto drugega, pri tem pa zazna in razume občutja in misli druge osebe oz. se vživi vanje, vendar se z njo ne poistoveti, kot se zgodi pri sočutju ali simpatiji. Tudi Wispé (1986) trdi, da je empatija ne glede na njen odnosni

7 Pot do omenjenega odnosa za terapevte in druge strokovne delavce ni preprosta. Zahteva namreč določeno stopnjo ranljivosti in poznavanje lastnih meja ter razumevanje svojih hudih stisk iz preteklosti, zaradi katerih se lahko strokovni delavec zapre in prepreči vzpostavitev harmoničnega stika z drugo osebo, to pa v sebi začuti sam in oseba, s katero komunicira (Siegel, 2010). 
vidik v samem jedru nevtralna, nasprotno pa pojav sočutja zahteva bolj poglobljeno angažiranost posameznika. Nadaljuje, da je poleg samega razumevanja pozitivnih in negativnih izkušenj ljudi ključen element empatije tudi sposobnost za razumevanje brez obsojanja. Vsebinsko se to ujema s čuječnostjo in pripomore k uspešnosti komisijske presoje.

Ker empatija omogoča, da se vživimo v drugo osebo tako, da se postavimo na njeno mesto in dobimo vpogled $v$ njene misli in čutenje, je empatija $v$ vseh odnosih nekaj pozitivnega in koristnega za vse vpletene. Dobrodošla je v vsakdanjih odnosih, nujna pa v terapevtski interakciji ${ }^{8}$ in podobnih profesionalnih odnosih (Simonič, 2010). Trdim lahko, da podobno kot empatija v terapevtskem odnosu zagotavlja klimo, ki omogoča večjo klientovo odprtost in sodelovanje (Walsh, 1998), tudi med komisijskim ocenjevanjem spodbuja odprtost, zaupnost in sproščenost prihodnjega uporabnika osebne asistence, saj zato bolj odprto spregovori o svojem življenju in potrebah po fizični pomoči druge osebe (osebnega asistenta). Ob tem ne trdim, da je mogoče proces strokovne presoje komisije neposredno primerjati s terapevtskim procesom, saj je cilj komisijskega obiska ugotovitev upravičenosti do storitve osebne asistence in ne terapevtska obravnava.

Čuječnost in empatijo razumem kot ključni element dobre komunikacije, od katere je zelo odvisna uspešnost ocene za osebno asistenco, saj naj bi celoten proces potekal kot odprt in iskren pogovor o potrebah osebe z oviranostjo. Pogovor s prihodnjim uporabnikom osebne asistence usmerja ocenjevalni obrazec ZOja, ki je bil zasnovan kot strokovno ocenjevalno orodje in naj bi zagotavljal objektivno resnične in primerljive rezultate, na podlagi katerih se oblikuje mnenje komisije o vsebini in številu ur osebne asistence. Praktična uporaba je pokazala, da ocenjevalni obrazec ZOja ni brez pomanjkljivosti, saj navodila za uporabo niso bila dovolj natančno zapisana, pogosto pa so tudi narobe razumljena. Leta 2020 je bil zato pripravljen nov ocenjevalni obrazec,

Simonič (2010) poudarja, da je empatija pomembna podlaga vsake terapevtske interakcije, ne glede na terapevtovo teoretsko usmeritev, saj ima univerzalen pomen. Med terapijo se terapevtova empatija kaže kot sposobnost za rahločutno poslušanje in spodbudno odzivanje na klienta, ki se lahko izrazi verbalno ali neverbalno s telesno govorico (Beres in Arlow, 1990). Pomembnost empatije v terapevtskem odnosu je posebej poudaril Carl Rogers, ki je znan kot utemeljitelj na klienta usmerjene terapije (ang. client-centered therapy), katere središče in izhodišče sta klient in njegov odnos s terapevtom. Rogers je obravnaval terapevtski odnos kot odnos pomoči, ki ima s splošnimi medčloveškimi odnosi skupno to, da gre za osebni odnos zaupanja, ki predpostavlja dostojanstvo človeške osebe. Prepričan je bil, da le terapevtski odnos, v katerem so doslednost, pristnost, empatija, visoka stopnja zanimanja in terapevtskega spoštovanja klienta, v klientu povzroči spreminjanje v pozitivni smeri (Rojnik, 1997). Tudi Rogers je jasno razlikoval med empatijo na eni strani ter sočutjem in simpatijo na drugi. Empatijo je razumel predvsem kot spoznavni pojav, ki ne zahteva terapevtove neposredne soudeleženosti v klientovem čustvenem doživljanju (Lamovec, 1987). Tudi relacijska družinska terapija, ki je v jedru psihobiološki model, poudarja pomen empatičnega odnosa med terapevtom in klientom, $v$ katerem terapevt zazna (pogosto prek lastnega telesa) in razume občutja klienta ter ga z vprašanji vodi v njihovo prepoznavanje in razrešitev. Poleg samega besednega izražanja ima v tem procesu ključno vlogo telo klienta, ki sporoča stisko, kakor tudi telo terapevta, ki jo zaznava (Gostečnik, 2013). 
ki naj bi pomanjkljivosti odpravil. Kljub temu menim, da je vsak človek odprto, svobodno in zapleteno ter predvsem presežno bitje, zato ga ni mogoče dojeti samo z znanstveno razlago oz. znanstvenimi raziskavami (Petkovšek, 2018; Juhant, 2006). Zato menim, da bo dopolnjen ocenjevalni obrazec tudi v prihodnosti treba še dopolniti, in sicer tako, da bo vključeval tudi informacije o čuječnosti, empatiji, občutkih in intuiciji.

\section{Raziskava o pomenu uporabniške izkušnje v komisijah za osebno asistenco}

\section{Metodologija}

Cilj raziskave je ugotoviti, kako osebe z gibalno oviranostjo in kroničnimi boleznimi, ki so zaprosile za komisijsko oceno pravice do osebne asistence, same ocenjujejo in vrednotijo pomen uporabniške izkušnje ${ }^{9}$ med obiskom komisije. Omejila sem se le na osebe z gibalno oviranostjo in morebitnimi pridruženimi kroničnimi boleznimi ali stanji, ki izvirajo iz osnovne diagnoze. Prav tako sem se omejila na osebe, ki jim poslovna sposobnost ni bila vzeta, in zato nimajo zakonitega zastopnika. Raziskava je potekala poleti 2019. V raziskavi je sodelovalo deset oseb, od teh pet žensk in pet moških. Gre za osebe, ki so se odzvale na javno prošnjo za sodelovanje v raziskavi prek družabnih medijev in elektronskih sporočil. Intervjuvane in vključene v raziskavo so bile vse osebe, ki so pokazale interes za sodelovanje. Število desetih sodelujočih in razmerje med spoloma je priložnostno, glede na takraten odziv uporabnikov osebne asistence na povabilo k raziskavi. Vse osebe, ki so sodelovale $\mathrm{v}$ raziskavi, so po komisijskem obisku pridobile pravico do osebne asistence in to pravico že aktivno uživajo.

V raziskavi sem uporabila raziskovalni polstrukturirani intervju, ki omogoča poglobljeno raziskovanje in razumevanje pomena uporabniške izkušnje $\mathrm{v}$ strokovnih komisijah za ovrednotenje pravice do osebne asistence. Intervjujev nisem opravila avtorica, ampak moja sorodnica, ki ni gibalno ovirana oseba, saj sem se hotela izogniti posrednemu vplivanju na odgovore intervjuvancev na podlagi podobne oviranosti. Ker sem avtorica prispevka oseba $\mathrm{z}$ osebno izkušnjo oviranosti, lahko napišem, da gre za uporabniško raziskovanje. Moj namen je bil pridobiti iskrene in resnične odgovore. Menim, da sem bila pri tem uspešna, saj si osebe $\mathrm{z}$ oviranostmi želijo pozitivnih sprememb (predstavljenih v rezultatih raziskave), to pa povečuje verjetnost iskrenosti. Pri interpretaciji in razumevanju zbranih podatkov sem uporabila analizo vsebine transkriptov intervjujev. V njih sem iskala prevladujoče teme in odgovore.

9 Uporabniško izkušnjo v kontekstu komisijske ocene razumem kot prispevek člana komisije, ki ima lastno izkušnjo oviranosti in že dlje časa uporablja storitve osebne asistence. Praktične izkušnje so element, ki dopolnjuje njegovo teoretsko znanje ali teoretsko znanje drugega člana komisije. 
Postopek zbiranja podatkov

Vprašalnik, ki je bil uporabljen v polstrukturiranih intervjujih, je sestavljen iz treh delov. Vprašanja v prvem sklopu so oblikovana $\mathrm{z}$ namenom pridobivanja demografskih podatkov, kot so: spol, starost, izobrazba, zakonski stan, bivanje v skupnem ali lastnem gospodinjstvu in vrsta naselja, v katerem posameznik živi. Drugi sklop vprašanj je splošen. V njem so bili intervjuvanci vprašani, ali o intimnih stvareh lažje odprto spregovorijo z osebo, ki ima podobno življenjsko izkušnjo, in komu najlažje pojasnijo svoje omejitve. ${ }^{10} \mathrm{~V}$ obeh primerih so bili intervjuvanci zaprošeni za pojasnilo odgovora in morebitne komentarje ter dodatne misli, povezane $\mathrm{z}$ vprašanji. $\mathrm{V}$ tretjem sklopu so bila vprašanja osredotočena na njihovo lastno izkušnjo obiska ocenjevalne komisije in ocenjevanja samega. Prvi del tretjega sklopa vprašanj je ugotavljal, ali so bili intervjuvanci pred oddajo vlog seznanjeni s pomenom in vlogo predstavnika uporabnikov, ali so v vlogi označili, da si predstavnika uporabnikov v svoji komisiji želijo, in ali je bila ta želja upoštevana. $V$ drugem delu tretjega sklopa vprašanj sem preverjala stopnjo sproščenosti, sprejetosti in razumljenosti med komisijskim ocenjevanjem in morebitno težnjo prihodnjega uporabnika osebne asistence po nerazkrivanju določenih intimnih podrobnosti njegovega življenja. Vprašani so bili tudi, katere podrobnosti želijo zadržati zase in zakaj. Tretji del tretjega sklopa vprašanj je bil namenjen zbiranju predlogov za povečanje kakovosti in sproščenosti med ocenjevalnim procesom in ovrednotenju pomena uporabniške izkušnje v komisijah za osebno asistenco. Vprašalnik je vseboval osemnajst vprašanj.

Vprašalnik sem pripravila raziskovalka, vendar je intervjuje pri sodelujočih na domu opravila tretja nevpletena oseba. Intervjuji so bili posneti na diktafon, transkripcije in preverjanje prepisa sem opravila raziskovalka. Prepise sem večkrat prebrala in zapisala ponavljajoče se besede, izraze in teme, ki so se pojavljali v odgovorih. Te sem potem analizirala in interpretirala.

\section{Demografija/vzorec}

V raziskavi je sodelovalo pet moških in pet žensk. Od tega so štiri osebe pripadale starostni skupini od 21 do 40 let in šest oseb starostni skupini od 41 do 60 let. Izobrazbena struktura vprašanih po višini presega splošno slovensko izobrazbeno raven (Statistični urad Republike Slovenije, 2017). Tri osebe imajo končano srednješolsko izobrazbo, tri visokošolsko, štiri osebe imajo univerzitetno diplomo. Zakonski status oseb, ki so sodelovale v raziskavi, je pester: tri osebe so bile samske, ena ločena, ena v zunajzakonski zvezi, pet ljudi je bilo v zakonski zvezi. Šest vprašanih živi v skupnem gospodinjstvu, od tega ena oseba z družino, in pet oseb z zakonskim partnerjem, štiri osebe pa imajo lastno gospodinjstvo. Živijo v različnih okoljih, največ - kar šest oseb

10 Omenjena hipoteza je bila posledica lastnega izvedenskega delovanja in opažanj v komisijah za oceno potrebe po osebni asistenci in raziskovanja občutka slišanosti, razumljenosti in podpore v vrstniških podpornih skupinah oz. skupinah za samopomoč (Nichols in Jenkinson, 2006). Skupna izkušnja pogosto omogoča varen prostor slišanosti, razumevanja, sproščenosti in pripravljenosti odkrito spregovoriti o sebi. Omenjeno trditev je podprla tudi moja kvalitativna raziskava. 
- živi v mestnem okolju, tri v vaškem okolju in ena v primestju. Demografski podatki so bili zbrani na domu uporabnikov osebne asistence med sproščenimi uvodnimi pogovori.

\section{Rezultati in razprava}

Osebe, ki so sodelovale v raziskavi, so večinsko (8x) potrdile, da o intimnih stvareh, ki zadevajo osebno nego, zdravstveno nego in uporabo različnih medicinsko-tehničnih pripomočkov lažje odprto spregovorijo z osebo, ki ima podobno življenjsko izkušnjo kakor same. To so v vseh primerih utemeljevale s prepričanjem, da oseba z lastno izkušnjo oviranosti bolje razume njihove potrebe po osebni asistenci in jim zato tudi bolj verjame, ko potrebo po tuji pomoči izrazijo.

Dve osebi sta navedli, da o omenjenih temah nič lažje ne govorita z osebo, ki ima podobno življenjsko izkušnjo. Omenjeno sta utemeljevali različno. Ena je menila, da ne občuti razlike, komu razlaga, in da nima predsodkov do nikogar. Druga pa je omenila, da je od lastne izkušnje oviranosti pomembnejše slušateljevo razumevanje in dojemanje njene izkušnje osebnih dejstev. Kljub vsemu je dodala, da slušatelji s podobnimi izkušnjami lažje razumejo njene izkušnje, saj je potrebnega manj pojasnjevanja, vendar to ne vpliva na njeno splošno sposobnost za pogovor o omenjenih temah.

Vprašanje: »Komu najlažje pojasnite svoje omejitve, zmožnosti, potrebe in način življenja? « je omogočilo še boljši vpogled v lastnosti članov strokovnih komisij, ki jih prihodnji uporabniki osebne asistence vrednotijo kot pozitivne. Ponavljajoče se teme so: podobna ali enaka diagnoza, ocenjevalec (8x), ${ }^{11} \mathrm{ki} \mathrm{je}$ odprt, brez predsodkov in ne diskriminira (7x), ter različni opisi empatičnosti in čuječnost, kakor jo zaznava in dojema oseba sama (6x).

Drugi sklop vprašanj se je nanašal na komisijski obisk prihodnjih uporabnikov osebne asistence in njihovo lastno stališče ter ovrednotenje uporabniške izkušnje. Kar osem vprašanih je odgovorilo, da so bili pred oddajo vloge za uveljavljanje pravice do osebne asistence seznanjeni s pomenom in vlogo predstavnika uporabnikov, le dve osebi pa sta dejali, da z vlogo in pomenom predstavnika uporabnikov nista bili seznanjeni.

Potem smo preverili, koliko sodelujočih je v svoji vlogi za uveljavljanje pravice do osebne asistence obkrožilo, da si v strokovni komisiji, ki jih bo obiskala na domu in ocenila potrebo po osebni asistenci, želi predstavnika uporabnikov. Teh je bilo sedem, tri osebe si predstavnika uporabnikov v svoji strokovni komisiji niso želele. To so utemeljile različno:

- z dejstvom, da oseba ni čutila potrebe po tem,

- z dejstvom, da oseba s pomenom in vlogo predstavnika uporabnikov ni bila seznanjena, sama pa se tudi ni pozanimala; oseba je hkrati izrazila obžalovanje: »Če bi vedel, da bodo taka osebna vprašanja, bi v komisiji hotel invalida",

- s strahom, da bi bil predstavnik uporabnikov oseba z oviranostjo, ki je drugačna od intervjuvančeve, to pa bi morda negativno vplivalo na oceno,

11 Številka označuje, kolikokrat se je med sodelujočimi v raziskavi pojavljal isti odgovor na vprašanje. 
saj bi oseba z drugo diagnozo lahko podzavestno enačila obe invalidnosti in spregledala ključne razlike.

Zanimiva je povezava med seznanjenostjo s pomenom in vlogo predstavnika uporabnikov ter izraženo željo osebe, da si v svoji strokovni komisiji predstavnika uporabnikov želi. Kar dve osebi od treh, ki si predstavnika uporabnikov v strokovni komisiji nista želeli, s pomenom in vlogo predstavnika uporabnikov nista bili seznanjeni. Od omenjenih dveh je ena oseba svojo odločitev obžalovala. Le en intervjuvanec je bil s pomenom in vlogo predstavnika uporabnikov seznanjen, vendar omenjenega v sestavi strokovne komisije ni želel in svoje odločitve ni obžaloval.

Preostalih sedem oseb si je v svoji sestavi strokovne komisije predstavnika uporabnikov po vrstah invalidnosti ${ }^{12}$ želelo. To utemeljujejo vsak s svojimi besedami, vendar odgovore združujejo določena skupna prepričanja.

- Kot prvo in najbolj prevladujoče se kaže prepričanje, da predstavnik uporabnikov bolje razume potrebo po osebni asistenci, zdravstveno stanje posameznika in ovire, s katerimi se v vsakodnevnem življenju srečuje posameznik. Omenjena utemeljitev se v odgovorih oseb, ki so si predstavnika uporabnikov v strokovni komisiji želele, pojavlja $7 \mathrm{x}$, se pravi pri vseh.

- Na drugem mestu se pojavlja prepričanje, da bo zaradi boljšega razumevanja predstavnik uporabnikov pripomogel $\mathrm{k}$ pravični ${ }^{13}$ in dobri oceni. Kaže se želja po pravični oceni o potrebi po osebni asistenci. Omenjena utemeljitev se v odgovorih pojavlja $3 \mathrm{x}$, se pravi skoraj pri polovici.

- Kot zadnje se pojavlja prepričanje, da predstavnik uporabnikov kot oseba z lastno izkušnjo oviranosti prihodnjemu uporabniku osebne asistence bolj verjame, ko opisuje svojo potrebo po fizični pomoči druge osebe, ker lahko izhaja tudi iz lastnih podobnih izkušenj. Omenjena utemeljitev se v odgovorih pojavlja $1 \mathrm{x}$.

Čeprav je sedem oseb v vlogi za uveljavljanje pravice do osebne asistence obkrožilo, da v sestavi strokovne komisije želijo predstavnika uporabnikov, pa ta želja pri vseh ni bila upoštevana. Predstavnik uporabnikov je bil član komisije v štirih primerih, v treh primerih pa Skupnost centrov za socialno delo ni mogla zagotoviti predstavnika uporabnikov zaradi pomanjkanja predstavnikov uporabnikov na geografskem območju, kjer osebe živijo. Prihodnje uporabnike osebne asistence so o tem obvestili po telefonu in jih prosili, ali smejo kot drugega člana komisije namesto predstavnika uporabnikov poslati strokovnjaka s področja socialnega ali zdravstvenega varstva.

Pomanjkanje izvedencev - predstavnikov uporabnikov na določenem geografskem območju je velik izziv za zagotavljanje pravice vlagatelja do izbire sestave komisije za osebno asistenco. Neljubo situacijo lahko pojasnim s tem, da prvo povabilo k usposabljanju izvedencev - predstavnikov uporabnikov ni doseglo vseh potencialno zainteresiranih oseb z oviranostjo, pa

Besedo invalidnost uporabljam, ker Zakon o osebni asistenci (2017) v 21. členu uporablja izraz »predstavnik uporabnikov po vrstah invalidnosti «.

13 Koncept »pravične ocene « za prihodnje uporabnike osebne asistence pomeni oceno, ki prepozna uporabnikove realne potrebe po osebni asistenci. $V$ praksi to pomeni, da se uporabniku dodeli toliko ur osebne asistence na teden, kolikor jih potrebuje. Ne manj in ne več. 
tudi s tem, da se je v času prvega usposabljanja izvedencev leta 2018 osebna asistenca izvajala le programsko, to pomeni, da nemalo oseb z oviranostmi ni prejemalo dovolj osebne asistence (ali sploh nobene), da bi se lahko udeležili večurnega usposabljanja v Ljubljani. Pomanjkanje osebne asistence je bil skupaj z oddaljenostjo kraja usposabljanja za marsikoga nepremostljiv logistični problem. Od stoenajstih izvedencev je le trideset izvedencev predstavnikov uporabnikov (Dremelj, Kobal Tomc, Smolej Jež in Berlot, 2020), ti pa so nesorazmerno porazdeljeni po Sloveniji. Več kot tretjina, kar enajst predstavnikov uporabnikov, deluje na območju Ljubljane, sledijo Pomurje s štirimi predstavniki uporabnikov, Maribor s tremi in Celje prav tako s tremi. Druga območja Slovenije imajo po dva ali le enega predstavnika uporabnikov (MDDSZ, 2020).

Poudariti je treba, da je realno število oseb z oviranostmi, ki so hkrati uporabniki osebne asistence, med izvedenci večje kot le navedenih trideset predstavnikov uporabnikov, saj nekaj oseb z oviranostmi v izvedenskih komisijah sodeluje kot izvedenci s področja socialnega varstva. ${ }^{14}$ Glede na to, da so imeli vsi izvedenci (zdravstva, socialnega varstva in predstavniki uporabnikov) enako usposabljanje, bi lahko ob jasni opredelitvi vloge v posamezni sestavi komisije in ob strinjanju izvedenca pomanjkanje predstavnikov uporabnikov odpravili tudi $\mathrm{z}$ začasno zamenjavo vlog $\mathrm{v}$ posamezni komisijski sestavi. Omenjena začasna rešitev se je leta 2019 v izjemnih primerih že izvajala. Dolgotrajna rešitev pa bi bila le vnovično povabilo oseb z oviranostmi, ki so uporabniki osebne asistence, k sodelovanju v komisijah za oceno potrebe po osebni asistenci.

Ratzka (2004) priporoča, naj se pri ocenah potrebe po osebni asistenci upošteva želje prihodnjih uporabnikov osebne asistence, prav posebej, koga želijo ob sebi med komisijskim ocenjevanjem. Meni, da se je vrstniška podpora pokazala za učinkovito pri ozaveščanju, učenju in širjenju informacij ter pri podpiranju in zagovorništvu uporabnikov osebne asistence. Tudi Mladenov (2020) v svoji raziskavi ugotavlja, da program izvajanja osebne asistence uporabniki osebne asistence vrednotijo kot dober le, če so vanj vpleteni na vseh stopnjah (od faze ocenjevalne komisije do vodenja lastne osebne asistence in izbiranja ekipe asistentov ter določanja njihovega delovnega časa). Upoštevanje želja in potreb prihodnjega uporabnika osebne asistence in pozitiven vpliv vrstniške podpore še dodatno podpirata in spodbujata vključevanje oseb z oviranostmi v komisije za osebno asistenco, še posebej kot predstavnike uporabnikov po vrstah invalidnosti, vendar ne omejeno nanje.

Le v enem primeru od desetih je bil poleg predstavnika uporabnikov tudi drugi član strokovne komisije (izvedenec s področja socialnega ali zdravstvenega varstva) oseba z izkušnjo gibalne oviranosti.

Potem sem hotela ugotoviti, ali se je oseba med komisijskim obiskom kadarkoli počutila nesproščeno, nesprejeto ali nerazumljeno. Sedem oseb je odgovorilo nikalno, tri osebe pa pritrdilno. Tri osebe, ki so se med obiskom komisije počutile nesproščene, nesprejete ali nerazumljene, so svojo izkušnjo različno opisale.

O številu oseb z oviranostmi, ki so hkrati tudi uporabniki osebne asistence in v izvedenskih komisijah sodelujejo kot izvedenci s področja socialnega varstva, ni uradnih podatkov. Moj zapis je plod opažanja z usposabljanj za izvedence in izkušenj s samih komisijskih obiskov. 
- Dve osebi sta poudarili, da člana komisije nista dobro razumela in sprejela tega, kar sta jima povedali. To so bile informacije, povezane z večjo potrebo po fizični pomoči druge osebe, ki so posledica zdravstvenih težav, slabega počutja, zmanjševanja energije čez dan in staranja.

- Ena oseba se je počutila nesproščeno zaradi namigovanja člana komisije, da ji lahko namesto osebnih asistentov vsakodnevno fizično pomoč popoldne zagotavlja mož. To ji je dalo vedeti, da član komisije ne verjame, da osebno asistenco potrebuje. Nelagodno pa se je počutila tudi zaradi vmešavanja člana komisije v njun zakon.

Vse tri osebe, ki so se med komisijskim ocenjevanjem počutile nesproščeno, nesprejeto ali nerazumljeno, so v vlogi za uveljavljanje pravice do osebne asistence obkrožile, da si v svoji komisijski sestavi želijo predstavnika uporabnikov, vendar jim to ni bilo omogočeno zaradi pomanjkanja predstavnikov uporabnikov na geografskem območju, kjer živijo. To kaže, da obstaja povezava med odločitvijo za vključitev predstavnika uporabnikov ${ }^{15} \mathrm{v}$ svojo strokovno komisijo in samo izkušnjo med ocenjevanjem glede na sestavo strokovne komisije, ki je posameznika obiskala.

V nadaljevanju so osebe odgovarjale na vprašanje, ali so med obiskom komisije obstajali določeni elementi in podrobnosti njihovega življenja ali potrebe in omejitve, ki jih niso želeli razkriti. Omenjeno vprašanje se ni nanašalo na samo razkritje ali zamolčanje določenih elementov njihovega osebnega življenja, ampak le na željo po nerazkritju.

Šest oseb je odgovorilo, da niso imele zadržkov pri razkrivanju podrobnosti svojega osebnega življenja, kar štiri osebe pa so dejale, da so obstajali določeni elementi in podrobnosti njihovega življenja ali potrebe in omejitve, ki jih niso želele razkriti. Med podanimi odgovori so lahko izbrale vse tiste, ki so se ujemali z njihovo izkušnjo obiska strokovne komisije. Podrobnosti svojega osebnega življenja, ki jih osebe niso hotele razkriti, se nanašajo predvsem na podrobnosti, povezane $\mathrm{z}$ osebno/intimno nego $(4 \mathrm{x})$, partnerskimi odnosi (3x), družinskim življenjem (2x), zdravstveno nego (1x) in uporabo medicinsko-tehničnih pripomočkov (1x).

Na podvprašanje, zakaj so osebe določene informacije svojega osebnega življenja želele zadržati zase, so odgovarjale različno. Pojavljali sta se dve pojasnili, ki so jih osebe s svojimi besedami izrazile na različne načine: pravica do določene stopnje zasebnosti (3x) in trditev, da so o sebi in svojih odnosih povedale že dovolj in da podrobnosti niso relevantne za mnenje strokovne komisije (2x).

Gotovo drži, da komisija lahko dobro presodi situacijo le, če pridobi vse potrebne podatke, ki jih za strokovno oceno potrebuje. Vendar ob tem ne smemo zanemariti, da je pravica do zasebnosti temeljna človekova pravica in v skladu z 22. členom Konvencije o pravicah invalidov tudi pravica vseh

15 Uporabniki osebne asistence so razkrili, da so se za vključitev predstavnika uporabnikov v svojo sestavo strokovne komisije odločili zaradi prepričanja, da bo predstavnik uporabnikov bolje razumel njihove potrebe po osebni asistenci, zdravstveno stanje in ovire, s katerimi se srečujejo v vsakodnevnem življenju. Pa tudi zaradi prepričanja, da bo na podlagi boljšega razumevanja predstavnik uporabnikov posamezniku verjel in izvedel pravično oceno. 
invalidov (Združeni narodi, 2006). Konvencija o pravicah invalidov v 17. členu zagotavlja pravico do osebne integritete, saj trdi, da ima vsak invalid enako kot drugi pravico do spoštovanja telesne in duševne integritete. V skladu s tem tudi 35. člen Ustave Republike Slovenije (1991) opredeljuje varstvo pravice do zasebnosti in osebnostnih pravic, po katerih se v Sloveniji vsem državljanom zagotavlja nedotakljivost telesne in duševne celovitosti, njegove zasebnosti in osebnostnih pravic. Slovenska Sodna praksa (2009) duševno integriteto opredeljuje kot ključen element za človekovo samouresničitev:

To pomeni, da mu je dopuščena iskrenost do samega sebe. To je pravica biti sam svoj in pravica do priznanja takšne izvirne, neponarejene podobe. Poleg tega človek potrebuje svoj mir, svoj svet zasebnosti, intime. To je svet, kjer lahko zaupa, da bo ostal skrit oziroma da bo o tem, koliko bo ostal skrit, odločal sam. Brez takšnega pristana (zaslombe) osebnosti ni duševne integritete.

Člana strokovne komisije lahko postavljata le osebna vprašanja, ki so nujna za uspešno oceno, še posebej pa morata biti pozorna na to, ko prihodnji uporabnik $\mathrm{z}$ besedami ali govorico telesa izraža nelagodje ob morebitnem vmešavanju $\mathrm{v}$ njegovo zasebnost, družino, dom.

Na drugo podvprašanje, komu bi najlažje razkrili podrobnosti svojega življenja ter potrebe in omejitve, so odgovorili enotno. Vse štiri osebe so odgovorile, da bi se najlažje odprle nekomu z istimi ali podobnimi življenjskimi izzivi. To odgovor lahko razumemo v kontekstu dejstva, da so od štirih oseb, ki so imele zadržke pri razkrivanju podrobnosti svojega osebnega življenja, kar tri osebe, ki so si v komisijski sestavi želele predstavnika uporabnikov, vendar ta ni bil na voljo. Četrta oseba sicer v svoji komisiji ni želela predstavnika uporabnikov, vendar je pozneje to odločitev obžalovala.

Osebe, ki so sodelovale v raziskavi, smo vprašali: »Kako bi povečali kakovost ocenjevanja in sproščenost med njim? « Ker je imela večina oseb več predlogov za izboljšanje ocenjevalnega procesa, jih navajam po pogostosti omemb. Devetkrat so kot izboljšavo predlagale vključenost oseb z isto ali podobno oviranostjo, kot jo ima prihodnji uporabnik osebne asistence. Od tega je le enkrat neposredno specificiran predlog o navzočnosti predstavnika uporabnikov po vrstah invalidnosti kot vloge člana komisije. To kaže, da je za prihodnje uporabnike osebne asistence pomembna predvsem navzočnost osebe s podobno oviranostjo, ne glede na to, ali je ta oseba v vlogi predstavnika uporabnikov, strokovnjaka s področja socialnega varstva ali strokovnjaka s področja zdravstvenega varstva.

Podobna priporočila v splošnejši obliki vsebuje tudi Konvencija o pravicah invalidov, saj v 4. členu priporoča, da se pri pripravljanju in izvajanju zakonodaje ter pri pripravi usmeritev za izvajanje konvencije in pri drugih postopkih odločanja, ki se nanašajo na invalide, njih dejavno vključi v sam proces in se z njimi tudi temeljito posvetuje. S tem se uresničujejo splošna načela konvencije, še posebej načelo nediskriminacije, polnega in učinkovitega sodelovanja in vključenosti v družbo ter načelo enakih možnosti (Združeni narodi, 2006). Uporabniki osebne asistence so k temu predlogu petkrat dodali še predlog, naj ima tudi drugi član komisije izkušnjo dela z osebami z oviranostjo, ki je ista ali 
podobna uporabnikovi. Konvencija v 4. členu pozitivno vrednoti in državam podpisnicam nalaga spodbujanje izobraževanja strokovnjakov in osebja, ki delajo z invalidi, o pravicah iz Konvencije, z namenom zagotavljanja pomoči in storitev, ki jih Konvencija predvideva (Združeni narodi, 2006). Pomemben del teh storitev je osebna asistenca, ki posameznikom z različnimi oviranostmi omogoča samostojno življenje in vključenost v družbo (19. člen). Štirikrat je bilo izraženo mnenje, naj bo oseba z lastno izkušnjo oviranosti tudi sama večletna uporabnica osebne asistence. Dvakrat se je pojavil predlog za boljše ocenjevalno orodje (vprašalnik) za delo komisij, enkrat pa možnost vpogleda v zdravstveno dokumentacijo, ki se nanaša na samo invalidnost. Le ena oseba ni imela predlogov za izboljšavo.

Na zadnje vprašanje: »Ali po vašem mnenju vključitev osebe s podobno življenjsko izkušnjo $\mathrm{v}$ komisije za osebno asistenco bistveno pripomore $\mathrm{k}$ uspešnosti ocenitve? « so vse osebe odgovorile pritrdilno, tudi tiste tri osebe, ki v svoji sestavi komisije niso želele predstavnika uporabnikov. Od omenjenih treh sta dve osebi le pritrdili, tretja pa je tudi pojasnila svoje stališče. Utemeljevala ga je s prepričanjem, da osebi s podobno življenjsko izkušnjo ni treba tako natančno pojasnjevati podrobnosti vseh svojih potreb in načina delovanja čez dan in vsakodnevnih potreb. Meni, da je ob vključitvi osebe s podobno življenjsko izkušnjo potrebno »manj pojasnjevanja, da se odrazi objektivno dejansko stanje«. To je zelo pomembno za osebe, ki se srečujejo $\mathrm{z}$ izzivi $\mathrm{v}$ komunikaciji in se nelagodno počutijo ob dodatnem pojasnjevanju.

\section{Sklep}

Rezultati raziskave so pokazali, da se večina vprašanih o intimnih stvareh, ki zadevajo osebno nego, zdravstveno nego in uporabo medicinsko-tehničnih pripomočkov, lažje odkrito pogovarja z osebo, ki ima podobno življenjsko izkušnjo ali vrsto oviranosti. Zato so $\mathrm{v}$ vlogi za uveljavljanje pravice do osebne asistence v večini obkrožili, da si želijo, da je en član strokovne komisije za podajo mnenja o številu in storitvah osebne asistence predstavnik uporabnikov po vrstah invalidnosti. To kaže, da je vloga predstavnika uporabnikov med prihodnjimi uporabniki osebne asistence dobro sprejeta in pozitivno ovrednotena. Še posebej, ko je oseba z lastno podobno ali isto izkušnjo oviranosti tudi sama večletna uporabnica osebne asistence.

Poleg dejstva, da je eden izmed članov komisije oseba s podobno vrsto oviranosti, prihodnji uporabniki osebne asistence pozitivno vrednotijo tudi osebnostne lastnosti in odnos članov komisije do osebe $\mathrm{z}$ oviranostjo, še posebej empatijo in čuječnost. Za prihodnje uporabnike osebne asistence je pomembno, da sami začutijo, da so vsi člani komisije odprti, brez predsodkov, vključujoči, empatični, neobsojajoči, pozorni in usmerjeni na osebo ter da so sposobni popolnoma razumeti, kar jim oseba z oviranostjo sporoča. Ob tem so izrazili tudi priporočilo, naj ima tudi drugi član komisije izkušnjo dela z osebami z oviranostjo, ki je ista ali podobna uporabnikovi.

Odgovori sodelujočih v raziskavi prav tako razkrivajo, da se z vključitvijo oseb $\mathrm{z}$ isto ali podobno oviranostjo $\mathrm{v}$ komisije za oceno potrebe po osebni 
asistenci poveča stopnja sproščenosti prihodnjih uporabnikov osebne asistence med samim ocenjevalnim procesom. Zato osebe $\mathrm{z}$ oviranostjo o sebi in svojih potrebah po pomoči druge osebe razkrijejo več podrobnosti, to pa ocenjevalni komisiji omogoča natančnejšo in realnejšo oceno posameznikovih potreb po vrstah storitev in številu ur osebne asistence. Zanimivo je, da celo tisti uporabniki osebne asistence, ki v svoji sestavi strokovne komisije niso želeli predstavnika uporabnikov, pozitivno vrednotijo vključitev osebe s podobno življenjsko izkušnjo v komisije za oceno potrebe po osebni asistenci, saj menijo, da to ključno pripomore k uspešnosti ocene. Pri tem je za prihodnje uporabnike osebne asistence pomembna predvsem navzočnost osebe s podobno oviranostjo, ne glede na to, ali je ta oseba v vlogi predstavnika uporabnikov, strokovnjaka s področja socialnega varstva ali strokovnjaka s področja zdravstvenega varstva. Treba pa je poudariti, da prav vloga predstavnika uporabnikov po vrstah invalidnosti najbolj zagotavlja vključitev osebe s podobno vrsto oviranosti.

Na podlagi rezultatov raziskave sem predstavila pomembnost vključitve oseb z oviranostjo v komisije za osebno asistenco, saj to izboljšuje počutje prihodnjih uporabnikov osebne asistence in uspešnost ocene, vendar se pozitivni vpliv omenjenega sodelovanja oseb z oviranostmi v komisijah za osebno asistenco s tem ne izčrpa.

Z vključitvijo oseb z oviranostmi, ki so hkrati uporabniki osebne asistence, se uresničujejo načela neodvisnega življenja, predvsem samoodločanja in prepričanja, da so uporabniki največji strokovnjaki, ki o osebni asistenci, njenem pomenu in izvajanju vedo največ. Tako smo se s slovenskim Zakonom o osebni asistenci (2017) kar najbolj oddaljili od vrste socialnega varstva, ki bi pokroviteljsko »skrbelo za osebe z oviranostmi«. Poleg samoodločanja se z vključevanjem oseb z oviranostmi v komisije za osebno asistenco in združenja za izvajanje osebne asistence podpirajo tudi koncepti samozastopništva, deprofesionalizacije in nemedicinskega modela ter deinstitucionalizacije.

Izkušnje iz tujine kažejo, da je z vključevanjem oseb z oviranostmi v vse faze programa osebne asistence, od pisanja predlogov zakona in pravilnika, vključevanja v komisije za osebno asistenco do samega izvajanje osebne asistence, poskrbljeno za pozitivno spremembo pri vsesplošnem vključevanju oseb z oviranostmi v lokalno skupnost in širšo družbo, povečajo se priložnosti za zaposlitev in izobraževanje, zato se izboljša tudi zdravstvena oskrba posameznika, njegova samozavest in kakovost njegovega življenja, kot jo sam doživlja in ocenjuje (Roulstone in Hwang, 2015).

Naj poudarim, da so osebe z različnimi oviranostmi, ki delujejo v komisijah za osebno asistenco, strokovnjaki na svojih področjih (kot predstavniki uporabnikov z izkušnjami koriščenja storitev osebne asistence ali kot strokovnjaki socialnega ali zdravstvenega varstva z ustrezno izobrazbo in izkušnjami), zato bi njihova odsotnost v komisijah za osebno asistenco lahko pomenila diskriminacijo. Prav diskriminacijo pa zunaj komisij za osebno asistenco doživljajo osebe z oviranostmi, ki so ekonomsko ranljivejše, saj imajo opraviti s predsodki delodajalcev, to pa povzroča visoko stopnjo brezposelnosti invalidov. Podatki Zavoda Republike Slovenije za zaposlovanje (2020) kažejo, da je kar 
$16,9 \%$ brezposelnih oseb invalidov, nemalo se jih uvršča med dolgotrajno brezposelne osebe. Delovanje oseb z oviranostmi v komisijah za osebno asistenco lahko posredno pripomore k reševanju tega problema, saj omogoča pridobivanje delovnih izkušenj, ki so ključne za zaposlitev, hkrati pa z manjšo finančno nagrado izboljša finančno stanje osebe z oviranostjo. Nezanemarljivo je tudi ozaveščanje v družbi, da je velik del oseb z oviranostmi sposobnih za delo in aktivnih, saj to na dolgi rok povečuje število potencialnih zaposlitev. Sodelovanje v komisijah za osebno asistenco lahko pripomore k izboljšanju blaginje oseb z oviranostmi, ne samo neposredno vpletenih, ampak tudi širše, prek vpliva na družbo, k vsesplošnemu spodbujanju enakih možnosti za vse.

Socialna krepitev in vključevanje oseb z različnimi oviranostmi v vsa področja javnega življenja pripomore k bolj odprti družbi (Open Society Foundations, b.d.), zato na podlagi te ocene in moje raziskave menim, da delovanje oseb z oviranostmi v komisijah za osebno asistenco pozitivno vpliva na samo oceno, na oba člana komisije in tudi v Sloveniji pripomore k bolj odprti družbi. Zato menim, da je v prenovljenem ocenjevalnem obrazcu in načinu ocenjevanja (iz leta 2020) koristno ozaveščati o pomenu predstavnika uporabnikov po vrstah invalidnosti in pospeševati sodelovanje strokovnjakov socialnega in zdravstvenega varstva, ki imajo tudi sami izkušnjo oviranosti.

\section{Viri}

Beres, D., \& Arlow, J. A. (1990). Fantasy and identification in empathy. V R. Langs (ur.), Clasics in psychoanalytic technique (str. 245-255). Northvale: Jason Aronson Inc.

Caputo Janhager, A. (2019). Understanding independent living in Sweden: an overview. Pridobljeno 1. 5. 2020 s https://www.independentliving.org/files/Understanding\%20 Independent\%20Living\%20in\%20Sweden\%20-\%20An\%20Overview.pdf

Doty, P., Kasper, J., \& Litvak, S. (1996). Consumer-directed models of personal care: lessons from Medicaid. The Milbank Quarterly: A Journal of Public Health and Health Care Policy, 74(3), 377-409.

Dremelj, P., Kobal Tomc, B., Smolej Jež, S., \& Berlot, L. (2020). Evalvacija uvajanja Zakona o osebni asistenci (Končno poročilo št. IRSSV 8/2020). Ljubljana: Inštitut Republike Slovenije za socialno varstvo.

Gostečnik, C. (2013). Relacijska paradigma in klinična praksa. Ljubljana: Frančiškanski družinski inštitut.

Gostečnik, C., Cvetek, R., Repič Slavič, T., \& Pate, T. (2016). Vloga religije v psihoanalizi. Bogoslovni vestnik, 76(1), 177-190.

Hribar Sorčan, V. (2008). O empatiji in intersubjektivnosti. Anthropos, 40(1/2), 11-25.

Inštitut Republike Slovenije za socialno varstvo (2018). Gradivo za člane strokovne komisije po Zakonu o osebni asistenci. Ljubljana: Inštitut Republike Slovenije za socialno varstvo.

Juhant, J. (2006). Človek v iskanju svoje podobe: filozofska antropologija. Ljubljana: Študentska založba.

Lamovec, T. (1987). Empatija. Anthropos, 17(5/6), 233-245.

MDDSZ (2020). Ministrstvo za delo, družino, socialne zadeve in enake možnosti. Lista izvedencev osebne asistence. Pridobljeno 17. 9. 2020 s https://www.gov.si/teme/osebna-asistenca/

Mladenov, T. (2020). What is good personal assistance made of? Results of a European survey. Disability \& Society, 35(1). Pridobljeno 13. 3. 2020 s https://www.tandfonline.com/ doi/epub/10.1080/09687599.2019.1621740?needAccess=true 
Mladenov, T., Pokern, Y., \& Bulic Cojocariu, I. (2019). PA checklist - a tool for assessing personal assistance schemes. Bruselj: European Network on Independent Living (ENIL).

Nichols, K., \& Jenkinson, J. (2006). Leading a support group: a practical guide. Berkshire: Open University Press.

Open Society Foundations (b.d.). Pridobljeno 15. 9. 2020 s https://www.opensocietyfoundations.org/voices/topics/disability-rights

Petkovšek, R. (2018). Svoboda med žrtvovanjem in darovanjem. Bogoslovni vestnik, 78(1), 33-51.

Ratzka, A. (ur.) (2004). Model National Personal Assistance Policy. Pridobljeno 13. 3. $2020 \mathrm{~s}$ https://www.independentliving.org/docs6/ratzka200410a.pdf

Rojnik, I. (1997). Medosebni odnosi kot osnova medosebnega komuniciranja v zakonu. Bogoslovni vestnik, 57(4), 511-528.

Roulstone, A., \& Hwang, S. K. (2015). Disabled people, choices and collective organisation: examining the potential of cooperatives in future social support. Disability \& Society 30(6), 849-864.

Saxton, M. (2002). » Now they have to treat us with respect «: homecare and personal assistance workers speak about recruitment, retention and unionization (Vladno poročilo 2002). ZDA: The World Institute on Disability v sodelovanju s Service Employees International Union (SEIU).

Siegel, D. J. (2010). The mindful therapist: a clinician's guide to mindsight and neutral integration. New York, London: W. W. Norton.

Simonič, B. (2010). Empatija kot temeljni antropološki odnos: od izročila preko Edith Stein do relacijske teorije (Doktorska disertacija). Ljubljana: Teološka fakulteta.

Sodna praksa (2009). VSL sodba I/ Cp 3003/2009. Pridobljeno 2. 4. 2020 s http://www. sodnapraksa.si/?q=du\%C5\%A1evna\%20integriteta\%20\&database[SOVS]=SOVS\&database[IESP]=IESP\&database[VDSS]=VDSS\&database[UPRS]=UPRS\&database[SEU]=SEU\&database[SOSC]=SOSC\&database[SOPM] =SOPM\&_submit=i\%C5\%A1\%C4\%8Di\&rowsPerPage=20\&page=0\&id=2012032113051694.

Statistični urad Republike Slovenije (2017). Socioekonomske značilnosti prebivalstva, Slovenija, 1. januar 2017. Pridobljeno 25. 9. 2019 s https://www.stat.si/StatWeb/News/ Index/7128/

Sušec, M. (2018). 1.1.2019 in osebna asistenca po Zakonu o osebni asistenci - bo ali ne bo? $M A Z ̌, ~ 27,20$.

Uršič, C. (ur.) (2008). Konvencija o pravicah invalidov: mednarodni sporazum o pravicah invalidov: lahko berljiv vodnik po konvenciji. Ljubljana: Ministrstvo za delo, družino in socialne zadeve. Pridobljeno 24. 11. $2021 \mathrm{~s}$ https://www.gov.si/assets/ministrstva/MDDSZ/ Invalidi/Konvencija/Konvencija_LB.pdf

Ustava Republike Slovenije (1991). Ur. l. RS, št. 33/1991.

Zakon o spremembah in dopolnitvah Zakona o osebni asistenci (2018). Ur. l. RS, št. 31/2018.

Zakon o osebni asistenci (2017). Ur. l. RS, št. 10/2017.

Zavod Republike Slovenije za zaposlovanje (2020). Registrirana brezposelnost. Pridobljeno 21. 2. 2020 s https://www.ess.gov.si/trg_dela/trg_dela_v_stevilkah/registrirana_brezposelnost/

Walsh, F. (1998). Strengthening family resilience. New York: The Guilford Press.

Wispé, L. (1987). The distinction between sympathy and empathy: to call forth a concept, a word is needed. Journal of Personality and Social Psychology, 50(2), 314-321.

Združeni narodi (2006). Convention on the rights of persons with disabilities and optional protocol. Pridobljeno 6. 3. 2020 s https://www.un.org/disabilities/documents/convention/convoptprot-e.pdf 
